\title{
SSTR1 wt Allele
}

National Cancer Institute

\section{Source}

National Cancer Institute. SSTR1 wt Allele. NCI Thesaurus. Code C51474.

Human SSTR1 wild-type allele is located within $14 q 13$ and is approximately $5 \mathrm{~kb}$ in length.

This allele, which encodes somatostatin receptor type 1 protein, plays a role in the regulatory inhibition and release of several hormones and secretory proteins. 